\title{
BIOLÓGIAI NAGYMOLEKULÁK SZERKEZETE - A GONDOLATTÓL A FELFEDEZÉSIG
}

\section{STRUCTURE OF BIOLOGICAL MACROMOLECULES - FROM IDEAS TO DISCOVERIES}

\author{
Hargittai István \\ az MTA rendes tagja, Budapesti Mǔszaki és Gazdaságtudományi Egyetem \\ istvan.hargittai@gmail.com
}

\section{ÖSSZEFOGLALÁS}

A huszadik század tudományának egyik nagy sikertörténete a biológiai nagymolekulák szerkezetének felderítése. A dolgozat párba állított kontrasztos tudósegyéniségek példáján mutatja be a kutatások és felfedezések természetét és a sikerek és kudarcok együttes jelentkezését ezekben a nagy formátumú pályákban. A dolgozatot a polimertudomány részben budapesti származású nagy úttörője, Herman F. Mark (1895-1992) emlékének ajánlom születésének 125. évfordulóján.

\section{ABSTRACT}

The elucidation of the structure of biological macromolecules is one of the brightest success stories of twentieth-century science. This sketch uses examples of the greatest careers of considerable contrast for presenting the nature of research and discoveries, and the joint appearances of success and failure. This paper is dedicated to the memory of Herman F. Mark (1895-1992), the great pioneer of polymer science, on the occasion of the $125^{\text {th }}$ anniversary of his birth.

Kulcsszavak: fehérjék szerkezete, nukleinsavak szerkezete, Phoebus A. Levene, Oswald T. Avery, William T. Astbury, J. Desmond Bernal, Linus Pauling, Max F. Perutz, Erwin Chargaff, James D. Watson

Keywords: structure of proteins, structure of nucleic acids, Phoebus A. Levene, Oswald T. Avery, William T. Astbury, J. Desmond Bernal, Linus Pauling, Max F. Perutz, Erwin Chargaff, James D. Watson 
A siker nem végleges, a kudarc nem végzetes, a folytatás bátorsága számít.

Winston Churchill

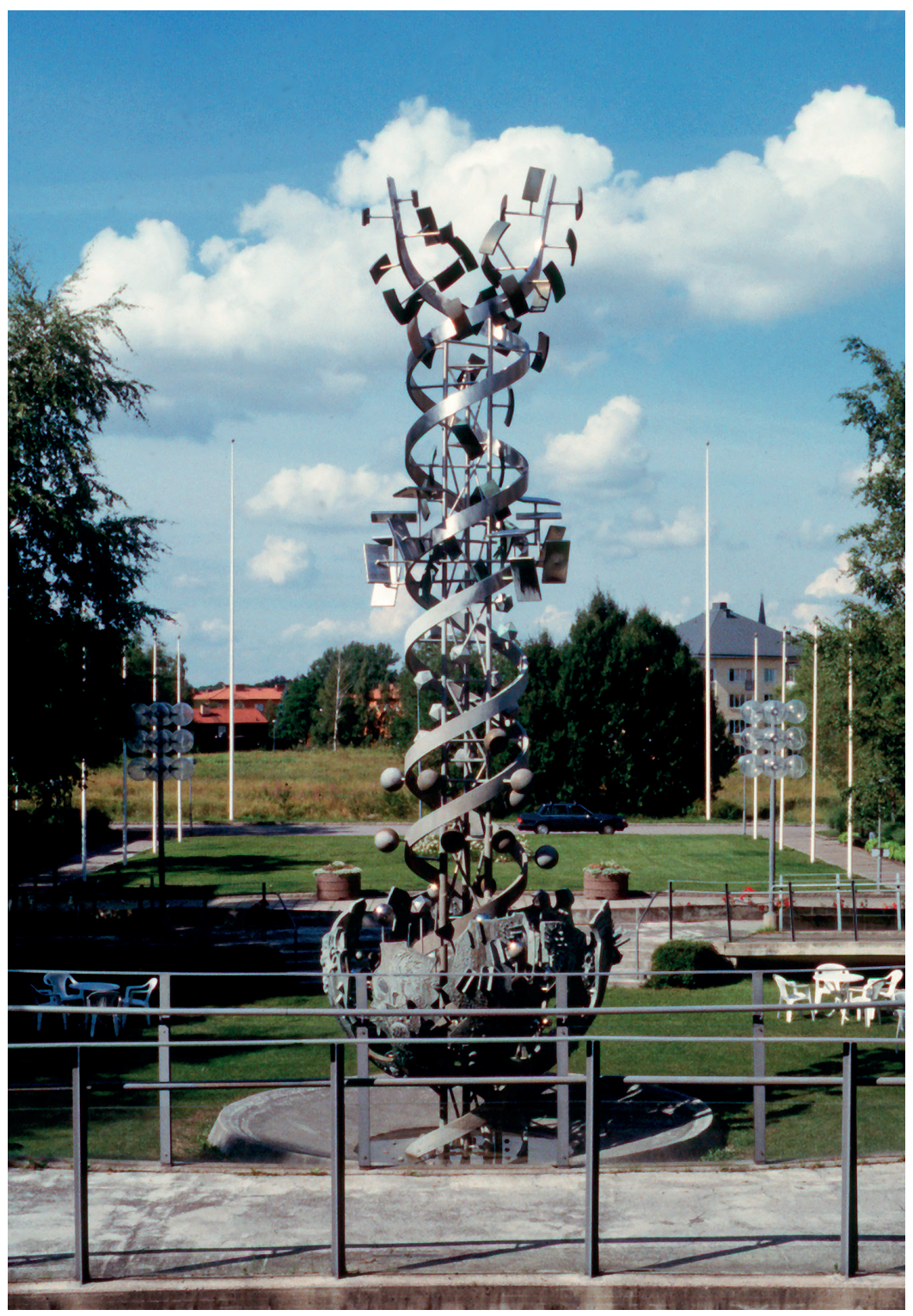

A DNS szerkezetének művészi megjelenítése -

Bror Marklund alkotása az Uppsalai Egyetemen. Hargittai István felvétele 1997-ből. Azóta a szobor környezetét teljesen beépítették 


\section{BEVEZETÉS}

A biológiai nagymolekulák szerkezetének felderítése a huszadik század tudományának egyik nagy sikertörténete. Ebböl a sikertörténetböl próbálok egy impresszionista képet felrajzolni. Pontosságra is törekvő egyszerüsítésemben egyéni teljesítményeket emelek ki, utalok sikerekre és kudarcokra, és tudósokat párba állítva adok hangsúlyt a felfedezésekből levonható tanulságoknak. Phoebus A. Levene (kiejtése: „levín”) és Oswald T. Avery révén szólok arról, hogyan derült ki az, hogy a DNS lehet az öröklés hordozója; William T. Astbury és J. Desmond Bernal révén arról, hogy a részlegesen rendezett kristályok és az ideálisan rendezett kristályok szerkezetkutatása milyen eredményekkel és buktatókkal járt. Linus Pauling és Max F. Perutz sikerei és kudarcai rávilágítanak a dogmákat elutasító kutatói magatartás termékenységére. Végül Erwin Chargaff és James D. Watson példája a gondolatok és az eszközök együttes hasznát hangsúlyozza a biológiai nagymolekulák kutatásában. A fentiekből látszik, hogy tárgyalásom messze nem teljes, és szubjektív elemeket is tartalmaz. Azt remélem, hogy a téma valamelyest nem szokványos feldolgozása új tanulságokat ajánlhat. A megidézett kutatók mind a tudomány óriásai, és azzal, hogy nemcsak sikereikre, hanem kudarcaikra is utalok, nem csökkentem az érdemeiket. Ellenkezőleg, szeretném érzékeltetni, hogy a tudomány frontvonalában tevékenykedőknek, az igazi úttörőknek, egyaránt van részük sikerben és kudarcban.

\section{LEVENE ÉS AVERY}

Phoebus A. Levene (1869-1940) orosz-zsidó származású amerikai biokémikus, generációk mentora, a Rockefeller Intézet munkatársa volt. ${ }^{1}$ Kutatásai kiterjedtek a fehérjékre, nukleinsavakra, szénhidrátokra, lipidekre és vitaminokra. Különösen a szénhidrátok területén alkotott maradandót. Jelen témánk szempontjából azonban 1909-ben felállított tetranukleotid hipotézise érdekes, amellyel a nukleinsavakat jellemezte, és amely három évtizeden keresztül egyik kutatási területe maradt (Hargittai, 2009). Ez a hipotézis a nukleinsavak nukleotid összetevőinek szabályos ismétlődését tételezte fel, ami sokáig akadályozta a DNS örökítő szerepének felismerését. A tetranukleotid hipotézis elhibázottsága csak Levene halála után derült ki.

Levene első érdeme ezen a területen a kérdés felvetése volt, amely a nukleinsavak kémiai összetételére vonatkozott. A válaszba csúszott hiba, de azt is érdemes figyelembe venni, hogy az miből eredt. Levene nem ismerte fel, hogy a nukleinsavak összetétele szervezetspecifikus, vagyis, hogy a négy nukleotid a legtöbb

\footnotetext{
${ }^{1}$ Akkor még Rockefeller Intézet, csak később alakult Rockefeller Egyetemmé.
} 
szervezetben nem azonos mennyiségekben van jelen. Sajnos a rendelkezésére álló kémiai analitikai eszközök meglehetősen pontatlanok voltak, és nem tudta megbízhatóan meghatározni a nukleotidok relatív mennyiségét az általa vizsgált szervezetekben. (Erre majd csak Chargaffnak lesz lehetősége a késői 1940-es években, lásd alább.) Ha túllépünk a hibás következtetésen, azt látjuk, hogy Levene hatalmas léptékkel vitte elöre a nukleinsavak megismerését. Amikor elkezdte vizsgálatait, csak annyit lehetett tudni, hogy a nukleinsavak foszforsavból, valamint nitrogént tartalmazó és nitrogént nem tartalmazó komponensekből állnak. Felállította az általa vizsgált nukleinsavak tapasztalati képletét, és az RNS-t is figyelembe véve megtalálta mind az öt bázist. Meghatározta a cukortartalmat és a foszforsav jelenlétét. További eredménye volt, és lehet, hogy ez volt a legfontosabb, hogy a nukleinsav-molekulák láncszerüek, vagyis nem (négytagú) gyürüs szerkezetủek, és a láncban a foszfát-észter-cukor-vázban a cukorhoz kapcsolódnak a bázisok.

Ahogy teltek az évek és az évtizedek, Levene finomította az eredményeit, és egyre kevésbé tekintette a tetranukleotid hipotézist csupán hipotézisnek. Egyik utolsó cikkében, amely harminc évvel az eredeti hipotézis felállítása után jelent meg, még mindig a nukleotidok lehetséges kapcsolódási módjait tárgyalta - láthatóan kételyei voltak az elért eredményekkel kapcsolatban. A tetranukleotid hipotézis azért is válhatott negatív kritika tárgyává, mert a hipotézisböl egyre inkább merev dogma lett, amihez hozzájárult Levene autokratikus karaktere és az iránta megnyilvánuló hatalmas tisztelet. A nukleinsavakat unalmas és buta molekuláknak tekintették, amelyek alkalmatlanok olyan bonyolult információ közvetítésére, ami megfelelne az öröklésnek.

Oswald T. Avery (1877-1955) volt annak a kutatócsoportnak a vezetője, amely a Rockefeller Intézetben foglalkozott az örökítőanyag azonosításával. Avery és két munkatársa, Colin MacLeod és Maclyn McCarty 1944-ben megjelentetett egy cikket a Journal of Experimental Medicine címú folyóiratban (Avery et al., 1944), amelyben gondos és kiterjedt bakteriológiai kísérleteik nyomán arra a következtetésre jutottak, hogy a DNS lehet az örökítőanyag. Ezzel a gén anyagának kémiai identitást adtak. A tanulmány befejező mondata hevenyészett fordításban így hangzik: A bemutatott bizonyíték megerősíti azt a meggyőződésünket, hogy a dezoxiribóz típusú nukleinsav a III. típusú pneumococcus átalakító elvének alapegysége. Az előzőleg még ismeretlen kémiai anyagot nevezte Avery ,átalakító elvnek".

Avery a cikk megjelenésének idejére már tekintélyes kutató volt, akit korábbi immunológiai eredményeiért többször ajánlottak Nobel-díjra. Professor emeritusként is tovább dolgozott. Csak a munka, a kíváncsiság hajtotta, a megismerés volt az ambíciója. Az elismerés annyira nem érdekelte, hogy az már a felfedezés megismertetését és elismertetését akadályozta. Szerény volt, és csendes, nem szeretett közönség elött beszélni. Ezzel szemben az ugyancsak a Rockefeller Intézetben 
dolgozó kiváló fehérjekutató, Alfred Mirsky nem fogadta el Averyék eredményét. Mirsky erősen hallatta a hangját, és nagy tekintélye volt a biokémikusok és sejtbiológusok körében. Azzal érvelt, hogy Averyék mintáiban a leggondosabb tisztítás mellett is maradhatott egy százaléknyi fehérje, ami óriási számú molekulát jelentett volna. Így nem lehetett kizárni azt a lehetőséget, hogy a fehérje az örökítóanyag. Ezt annál is könnyebb volt elképzelni, mivel a nukleinsavakról még erősen élt a tetranukleotid hipotézis által sugallt elképzelés. Avery példája azt mutatja, hogy nem elég világraszóló felfedezést tenni, azt el is kell fogadtatni. Averyék felfedezése néhány évvel később egy sokkal kevésbé körültekintő kísérlet nyomán nyert általános elfogadást, amikor a kutatóközösség már kész volt arra, hogy befogadja ezt az eredetileg rendhagyónak tủnő felfedezést.

\section{ASTBURY ÉS BERNAL}

William T. Astbury (1898-1961) és J. Desmond Bernal (1901-1971), mindketten brit krisztallográfusok, fontos szerepet játszottak a biológiai nagymolekulák szerkezetének felderítésében. Kevés olyan eredményes eszköze volt a huszadik században a tudományos felfedezéseknek, mint a röntgenkrisztallográfia, amely úgyszintén a században született. A lenyügöző eredményesség és hatalmas siker abban nyilvánult meg, hogy mára már a kristályos anyagok százezreiben feltárták a szerkezetet, az atomok és molekulák térbeli elhelyezkedését.

Az csak fokozatosan tudatosult a kutatókban, hogy a természet anyagai és az ember által elóállított és használt anyagok között viszonylag kevés a rendezett kristályszerkezetủ. A rendezetlen szerkezetủ anyagok legalább olyan fontosak lehetnek, mint a kristályosak. Idővel a röntgenkrisztallográfia sikere az előrejutás gátja is lett, mert mindeközben majdnem elhanyagolták a rendezetlen szerkezeteket. Astbury kivétel volt, és ebből a szempontból nem a röntgenkrisztallográfiai kutatások fó vonalába tartozott. A Leedsi Egyetem oktatójaként szoros kapcsolatban állt a környékbeli textiliparral, korán kezdett szálas anyagokkal foglalkozni, és kiterjedten alkalmazta a röntgendiffrakciós módszert biológiai nagymolekulák vizsgálatára. Bernal is egyik kezdeményezője volt a fehérjék röntgendiffrakciós szerkezetvizsgálatának. Amikor először sikerült fehérjékről diffrakciós képet készítenie, tudta, hogy új korszak nyílik az élet titkainak feltárásában. Annál sajnálatosabb, hogy nem folytatta ezt a kezdeményezést. Bernal inkább látnok volt, mintsem a részletekben elmélyülő kutató. Elindított nagyszabású programokat, hogy aztán tanítványai vigyék azokat végig.

Mindkét vezető brit krisztallográfus, Astbury és Bernal is egy bizonyos ponton úgy gondolta, hogy feloszthatják egymás között a krisztallográfiai kutatásokat. Mindketten felismerték a teljesen és a részlegesen kristályos szerkezetek közötti különbséget, és Bernal a kristályos anyagokat választotta, Astbury az amorf és 
ennek megfelelően zavaros mintákat. Astbury vizsgálta a lényegében amorf nukleinsavakat és Bernal a kristályos komponens nukleozidokat. Bernal a Londoni Egyetemen dolgozott, és az ő alapításával és vezetésével indult el a világ első krisztallográfiai tanszéke. Kezdetben Bernal választása tünt szerencsésebbnek, de aztán az ellenkezője következett be. A szálas anyagok helikális szerkezetének diffrakciós képén kevesebb információhordozó folt van, mint a háromdimenziós kristályok szerkezetének diffrakciós képén, viszont az előbbi közelitő értelmezése könnyebb.

Ellentmondásosnak hangzik, hogy a több információt hordozó vizsgálat kevésbé eredményes, mint a bonyolult molekulák vizsgálata, de itt nem a pontosságról van szó, hanem az elemzés stratégiájáról. Ennél is lényegesebb, hogy a szálas anyagú biológiai nagymolekulák kutatása messze fontosabbnak bizonyult, mint a „tökéletes” kristályoké. Ilyen értelemben Bernal rosszul választott. Hamarosan felismerte, hogy a tudományos kutatásban egy stratégiai hiba ugyanolyan súlyos vagy súlyosabb lehet, mint egy ténybeli tévedés (Bernal, 1968). Astbury neve sem szerepel a biológiai nagymolekulák szerkezetének végső felfedezői között, de ott van az úttörők között. Diffrakciós felvételeinek minősége elmaradt a valamivel későbbi felvételek minőségétől. De vele szemben, a nagyobb tudós Bernal alulmaradt abban, hogy mit láttak a leginkább perspektivikus iránynak a tudományukban.

\section{PAULING ÉS PERUTZ}

Linus Pauling (1901-1994) kutatói pályája a korábban alig ismert és vele együtt felemelkedő Kaliforniai Technológiai Egyetemhez (California Institute of Technology) kötődött. Az 1930-as években kezdett foglalkozni a fehérjék szerkezetével. Ebben támaszkodhatott Astbury megfigyeléseire, aki előtte a haj, gyapjú és más rostokról készített röntgendiffrakciós felvételeket. ${ }^{2}$ Astbury megállapította, hogy a nedves szálak diffrakciós képe jellegzetesen különbözik a száraz szálakétól. Ezt a polipeptid lánc kétféle alakjával magyarázták. A nyújtott forma a béta-keratin volt, amely végül a béta-redős lap nevet kapta. A csavarodott alakú alfa-keratint később alfa-hélixnek nevezték el, de az már a szerkezet ismeretében történt.

\footnotetext{
${ }^{2}$ Az 1920-as évek elején Berlinben Polányi Mihály az elsők között ismerte fel a szálas anyagok szerkezetfelderítésének jelentőségét. Ezért végzett röntgendiffrakciós kísérleteket cellulózrostokon. Krisztallitokat figyelt meg, amelyek a rostok irányában rendeződtek, és ugyanilyen kristályorientációt figyelt meg fémdrótokban. Amikor megnyújtotta a cellulózrostokat, hasonló változást mutattak, mint a fémdrótok hideghúzás nyomán. Ezek elöremutató kutatások voltak, de akkor még nem álltak rendelkezésre a megfelelő eszközök a folytatásukra, és Polányi témát váltott (Hargittai, 2016).
} 
Pauling az alfa-keratin szerkezetét akarta meghatározni, és ehhez stratégiát dolgozott ki, olyan stratégiát, amelyet abban az időben egyedül csak ő tudott megvalósítani (Hargittai, 2010). Egyrészt támaszkodott hatalmas szerkezeti kémiai tudására, amely elsősorban kismolekulákra vonatkozó elektrondiffrakciós kutatásaiból származott. Másrészt felismerte a modellépítés jelentőségét. Első lépésként megjósolta a polipeptid lánc méreteit, majd vizsgálta a lehetséges konformációit, hogy eljusson egyetlen vagy legalábbis kisszámú lehetséges konformációig, amely vagy amelyek összhangban vannak a röntgendiffrakciós képpel. A kismolekulák szerkezetéből levont legfontosabb következtetése a peptidkötés körüli konfiguráció síkbelisége vagy közel síkbelisége volt. Ez jelentősen csökkentette a lehetséges szerkezetek számát. Modelljének bizonyos jellegzetességei azonban továbbra sem voltak összhangban a diffrakciós képpel. Az ellentmondásokat akkor nem tudta feloldani, és évekre abbahagyta a vizsgálatot. Akkor még megtehette ezt, mert alig volt verseny a tudományos kutatásokban.

Amikor 1948-ban visszatért a témához, szimmetriameggondolások alapján drasztikus egyszerüsítést vezetett be a modelljébe. Eltekintett attól, hogy a peptidláncot akár húsz különféle aminosav alkothatja. Az, hogy a peptidlánc szerkezete szempontjából az aminosavakat egyenértékünek tekintette, döntően segítette a modell alkalmazhatóságát. A következő lépés az volt, hogy modellezéssel felépítse a peptidláncot. Ebben egy, még egyetemista korában hallott matematikai tétel segítette, amely szerint a forgatás-eltolás az a szimmetriamúvelet, amely egy aszimmetrikus tárgyat, mondjuk egy L-aminosavat egy másik, ugyanolyan L-aminosavba viszi át. Ez a művelet tehát egy tengely körüli elfordítást egy, a tengely mentén történő eltolással kombinál, ami az ismétlések nyomán csavart hoz létre. Pauling felrajzolta a peptidlánc modelljét egy papírlapra, majd a papírlapot henger alakúra tekerte. Az így kialakult hélixet a létrejövő geometria szerint hidrogénkötések stabilizálták. Mellőzve itt a részleteket, összesen két elrendezést talált, amelyek bizonyos kritériumokat, köztük a peptidcsoportok síkbeliségét, kielégítették. Így jutott el az alfa-csavar vagy alfa-hélix modelljéhez, amely a két lehetséges szerkezet egyike volt.

Modellezésében két dolgot tartok különösen jelentősnek. Az egyik, hogy bátran alkalmazott közelítéseket, bizonyos nagyvonalúságot. A modellezésnek éppen ez a lényege, hogy bizonyos hatásokat figyelembe vesz és másokat elhanyagol. A másik, hogy ragaszkodott szerkezeti kémiai tényekhez, nevezetesen, a peptidkötés körüli síkbeliséghez vagy közel síkbeliséghez. Pauling érdeme és sikerének titka az volt, hogy képes volt dogmákkal szakitani. Így szakított a lehető legnagyobb szimmetriát feltételező dogmával, és elfogadhatónak tartotta az aminosavak nem egész számú ismétlődését a modelljében, arról nem is beszélve, hogy azt is elhanyagolta, hogy akár húszféle különböző aminosav szerepelhet egy polipeptid láncban. 
Felfedezésének jelentőségét kiemeli, hogy ebben az időben egy kiváló brit csoport az angliai Cambridge-ben ugyancsak dolgozott a polipeptid lánc szerkezetén. Húsz lehetséges szerkezetet publikáltak, amelyek közül egy sem illett az alfa-keratinra, és amelyben figyelmen kívül hagyták a peptidcsoport síkbeliségére vonatkozó ismereteket. A csoport tagjai, a már Nobel-díjas W. Lawrence Bragg, valamint két későbbi Nobel-díjas, Max Perutz és John Kendrew voltak. Bragg volt a röntgenkrisztallográfiai szerkezetkutatás úttöröje, Perutz és Kendrew pedig a kvantitatív fehérje-szerkezetkutatás úttöröje.

Max F. Perutz (1914-2002) a bécsi születésü brit krisztallográfus a fentiek szerint megégette magát az alfa-keratin szerkezetvizsgálatában. A munkát azonban nem adta fel. Kereste a módját annak, hogy kutatásait megbízhatóvá és a nagymolekulájú fehérjék irányában minél kvantitatívabbá tegye. Az 1950-es években még erösen tartotta magát az a nézet, hogy a röntgendiffrakciós adatok jó része felhasználhatatlan marad, mert a fázisra vonatkozó információ elvész. Ezt hamarosan megdöntötte Herbert Hauptman és Jerome Karle, akik matematikai közelítéseket felhasználó, ún. direkt módszerekkel utat nyitottak a nagymolekulák pontosabb szerkezetmeghatározása felé. Addig azonban más megoldásokat kellett keresni. Ebben jutott mérföldkő jelentőségü eredményre Perutz, majd nyomában a vele dolgozó Kendrew. Perutz azt a kismolekulákra akkor már évek óta alkalmazott megközelítést használta fel a fehérjemolekulákra, hogy egy vagy több nehézatomot vitt be a nagymolekulába, és ezzel a diffrakciós képet információban gazdagabbá tette. A módszert izomorf helyettesítésnek nevezik. A hemoglobinkristály diffrakciós képét egy olyanéval hasonlította össze, amelyhez előzőleg két higanyatomot kapcsolt. Addig például 58-atomos molekulára alkalmazták ezt a módszert, Perutz molekulája 10000 atomot tartalmazott. Perutz érdeme összefoglalóan az volt, hogy más körülményekre és más feltételekkel kidolgozott módszert alkalmazott a biztos siker igérete nélkül olyan új rendszerre, amit más meg sem kisérelt volna.

Perutz felfedezésével feledtette az alfa-keratin vizsgálatával kapcsolatos fiaskót, és Kendrew-val közösen 1962-ben Nobel-díjat kapott. Paulingot már 1954ben kitüntették Nobel-díjjal az alfa-hélix felfedezéséért. Az elismerésben szerepeltek a kémiai kötés természetének felderítésében szerzett érdemei is. Ennek Pauling annál is inkább örült, mert Nobel-díja idejére már neki is volt egy látványos fiaskója: hármas hélixes szerkezetet javasolt a DNS-re, amiről szinte már publikálásával egy időben kiderült, hogy hibás elképzelés. Pauling szinte triviális kémiai szempontokat hagyott figyelmen kívül a hármas hélixes model publikálásával. A hármas hélixes modelhez észszerü müködési magyarázatot sem lehetett rendelni. Az alaphiba az volt, hogy nem vette elég komolyan a nukleinsavak szerkezetkutatását, szemben a fehérjékkel, még Avery felfedezése után sem. Ezzel nem volt egyedül. 


\section{CHARGAFFÉS WATSON}

Avery felfedezése nyomán csak két jelentős kutató kezdett széles körü programba a nukleinsavak vizsgálatával. Egyikük, Joshua Lederberg baktérium-genetikai felfedezéseiért kapott Nobel-díjat, és nem tartozik szükebb tárgyunkba. A másik, Erwin Chargaff (1905-2002) döntő felfedezésekkel járult hozzá a nukleinsavak szerkezetfelderítéséhez. Az Osztrák-Magyar Monarchia távoli keleti vidékéröl származott, de a köztudatba igazi bécsi polgárként vonult be, aki aztán Amerikába emigrált. A Columbia Egyetem tekintélyes biokémia professzora volt, amikor Avery és munkatársai 1944-es cikke nyomán lesöpörte asztaláról összes addigi, egyébként sikeresen művelt témáját, és átállt a DNS vizsgálatára. Két alapvető eredményt ért el. Az egyik, hogy a DNS szervezetspecifikus, és ezzel megdöntötte a Levene-féle dogmát, amely szerint a DNS, megfelelően a közel negyvenéves tetranukleotid hipotézisnek, független attól, hogy melyik szervezetben fordul elö.

A DNS szervezetspecifikusságát csak megbízható kromatográfiás vizsgálatokkal lehetett megállapítani. Eddig kevés szó esett a kutatási eszközök jelentőségéről, legfeljebb csak közvetve. Ilyen kutatási eszköz a röntgendiffrakció és a Paulingnál ugyancsak megemlített elektrondiffrakció is, és ilyen a kromatográfia és többféle változata. ${ }^{3}$

Chargaff második megállapítása abból a megfigyelésből származott, amely szerint az adott szervezettől függetlenül az adenin mennyisége egyenlő a timinével, és a guanin mennyisége egyenlő a citozinéval. Ez olyan megfigyelés volt, amelyet nehéz volt elfogadni, mert akkor még nem volt rá racionális magyarázat. Ehhez a megállapításhoz bátorság kellett, és nem járt kockázat nélkül. A mérési

${ }^{3}$ I. Erzsébet angol királynő korától kezdve számon tartható, hogy az eszközök fejlesztése, az új kutatási eszközök megjelenése milyen mélyreható, gyakran forradalmi változásokat hozott magával a tudományban. I. Erzsébet kedvező feltételeket teremtett ahhoz, hogy a kontinensröl Angliába vonzzon eszközkészítőket. Azok nemcsak kiváló eszközöket készítettek, de angol tanítványaikat is megtanították az eszközkészítés fortélyaira. Ez elökészítette a körülményeket az angliai tudományos forradalomra. Ugyanígy előkészítő volt Francis Bacon tudományfilozófiája, hogy mire maguk a tudósok elérkezettnek látták az időt arra, hogy 1660-ban megalapítsák azt a szervezetet, amelyből a Royal Society kifejlődött, ehhez minden együtt legyen. A kísérletezés, a megfigyelés volt a tudományos kutatás alapja, és ebben mindig élenjáró eszközök segítettek. A huszadik században ezek közül is kiemelkedett, a röntgenkrisztallográfia mellett a kromatográfia. A kromatográfia nem egy csapásra vált a felfedezések eszközévé, és ezért van az is, hogy az eredeti úttörőre, Mihail Cvetre (1872-1919) ritkán emlékeznek. Az 1900-as évek elején született felfedezésének Nobel-díjjal történő elismerésére csupán egyetlen ajánlás érkezett, az is nem sokkal halála előtt. Voronyezsi sírkövének felirata: Felfedezte a kromatográfiát, amely elválasztja a molekulákat, de összekapcsolja az embereket. Később, kromatográfiával kapcsolatban születtek Nobel-díjak. 
adatok ugyanis jelentősen szórtak. Nem kis dilemmájába került Chargaffnak, hogy előálljon ezzel a megállapítással, de megtette, és az idő aztán ragyogóan igazolta. Ez a felfedezés iskolapéldája annak, amiről Polányi Mihály nyomán Wigner Jenő mondta 1963-as stockholmi beszédében, hogy a szabályszerüségek megfigyelése és megállapításuk az igazi tudomány. Chargaff az említett bázis-ekvivalenciákat figyelte meg, ami a bázispárok felismerését jelentette, még ha nem is jutott el a végső következtetésig (Hargittai, 2005). Elmulasztotta ugyanis azt a kérdést feltenni, hogy Miért? Ez a mulasztás aztán kimondva és kimondatlanul élete végéig kísérte és kísértette. Legnagyobb tudományos sikere a bázispárok felfedezése és legnagyobb tudományos kudarca a miért kérdés elmulasztása volt.

James D. Watson és Francis Crick mérföldkő jelentőségü, alig egyoldalas Nature-beli, 1953-as dolgozata Chargaff munkái közül mindössze egyik rövid cikkére hivatkozik (Watson-Crick, 1953). Chargaff még így is jobban járt, mint Rosalind Franklin, akire egyáltalán nem hivatkoztak. Ez csak súlyosbította annak ódiumát, hogy Franklin és doktoránsa, Raymond Gosling eredményeihez Watson és Crick Franklinék tudomása nélkül jutottak hozzá. Ez a kiváló Watson-Crick szerzőpáros korszakos eredményét nem csökkenti, csak emberi/ erkölcsi vonatkozásban árnyékot vet rájuk. Watson és Crick együttmüködése a tudománytörténet egyik legszebb példája két tudós egymást kiegészítő közös munkájára, amiről már sokat szóltak. Én most a tanulságos kontraszt kedvéért szerepeltetem együtt Chargaff és Watson személyiségét. Chargaff testesítette meg az elmélyülö és maximális felkészültségü, kiterjedt klasszikus mủveltségü kutatót. James D. Watson (1928-) meg, akkori mivoltában azt az utóbbi időkben nem ritka biológus kutatót, aki nagyon gyorsan eljut a tudomány frontvonalába, hogy aztán ott alkosson valami rendkívülit. Watson azonban ezek között nem volt tipikus, mert a felfedezés után nem tünt el az ismeretlenségben vagy valamelyik biotech vállalat vezető részvényeseként. Évtizedekig a tudományos közösség élvonalában maradt mint tudománypolitikus, kutatásirányító és népszerü tudományos irodalom és tankönyvek szerzője. Csak több esetben is elhangzott, szexistának és rasszistának is minősíthető, meggondolatlan nyilatkozatai lökték le a piedesztálról. Úgy tünik, Watson abbéli igyekezetében, hogy sokkolja a hallgatóságát, túlbecsülte annak toleranciáját. Watson, aki sokat tett könyveivel azért, hogy emberközelbe hozza a tudományos kutatókat, éppen emberségből bukott el (Hargittai, 2008). A DNS kettős hélix szerkezetének felfedezése azonban a modern biológia és orvosbiológia kiindulási pontja maradt és következményei továbbra is ott szerepelnek a korszerü és egyre inkább egyénre szabott gyógyítás lehetőségei között.

Watson és Crick felfedezésükhöz felhasználták a felgyülemlett szerkezeti kémiai adatokat, a modellépítés módszerét, mindkettőt elsősorban Pauling nyomán. Felhasználták továbbá Rosalind Franklin és Raymond Gosling kiváló 
röntgendiffrakciós felvételét, amely egyértelmúen utalt a helikális szerkezetre, és azokat az elméleti eredményeket, amelyek a helikális szerkezetek röntgendiffrakciós leírását jelentették. A lehető legtermékenyebb légkörben dolgoztak az angliai Cambridge Cavendish Laboratóriumában a brit Orvostudományi Kutatási Tanács anyagi támogatásával. Nagyon sok körülmény szerencsés öszszejátszása segítette munkájukat, de ez nem csökkenti egyéni teljesítményük értékét. Watson nem véletlenül került ebbe a helyzetbe. Az Indiana Egyetemen olyan témában szerzett PhD-fokozatot, amelyet nem látott érdemesnek folytatni. Európai ösztöndíjas tanulmányútja sem jelentett számára megfelelő kihívást. Még azon az áron is a változtatásra szánta el magát, hogy ez az ösztöndíja elvesztését jelentette. Azt a témát kereste meg, amelyet a legizgalmasabbnak tartott. Az sem zavarta, hogy nem voltak meg azok az alapjai, amelyek a szokásos kritériumok szerint képessé tették volna a téma eredményes müvelésére. Mégis ragyogó eredményre jutott a kiváló partner társaságában, a kedvező körülményeknek, de elsősorban mégis a saját tehetségének és elszántságának köszönhetően. Watson és Crick csak javaslatot tett a DNS szerkezetére, de a javasolt kettős hélix szerkezet, ha nem is azonnal és nem is rögtön elsöprő módon, de magával ragadta a tudományos közösséget és aztán a tágabb közéletet is. Sokan emlegetik a relativitáselméletet, de alig van, aki tudja, hogy ilyenkor miröl beszél. A kettős hélix (vagy - gyakran - a kettős spirál) emlegetése inkább jár együtt valamiféle értéssel is. A fogalom közkincs lett, a vizuális megjelenés mindenütt jelen van, és népszerü. Nincs még egy annyira egyetemes ikonja a tudománynak, mint a kettős hélix.

\section{IRODALOM}

Avery, O. T. - MacLeod, C. - McCarty, M. (1944): Studies on the Chemical Nature of the Substance Inducing Transformation of Pleumococcal Types: Induction of Transformation by a Desoxyribonucleic Acid Fraction Isolated from Pneumococcus Type III. Journal of Experimental Medicine, 79, 137-158. DOI: 10.1084/jem.79.2.137, https://www.ncbi.nlm.nih.gov/pmc/articles/ PMC2135445/pdf/137.pdf

Bernal, J. D. (1968): The Material Theory of Life. Labour Monthly, July, 323-326. https://bit. $1 \mathrm{y} / 2 \mathrm{~J} 3 \mathrm{os} 0 \mathrm{q}$

Hargittai I. (2005): Chargaff Centennial: Erwin Chargaff (1905-2002). Structural Chemistry, 16, 455-456. https://www.researchgate.net/publication/225901547_Chargaff_Centennial_Erwin_ Chargaff_1905-2002

Hargittai I. (2008): Doktor DNS: Öszinte beszélgetések James D. Watsonnal. Budapest: Vince Kiadó

Hargittai I. (2009): The Tetranucleotide Hypothesis: A Centennial. Structural Chemistry, 20, 753-756. DOI: 10.1007/s11224-009-9497-x, https://link.springer.com/article/10.1007/s11224009-9497-x 
Hargittai I. (2010): Linus Pauling's Quest for the Structure of Proteins. Structural Chemistry, 21, 1-7. DOI: 10.1007/s11224-009-9565-2, https://link.springer.com/article/10.1007/s11224-0099565-2

Hargittai I. (2016): Michael Polanyi - Pupils and Crossroads - on the $125^{\text {th }}$ Anniversary of His Birth. Structural Chemistry, 27, 1327-1344. DOI: 10.1007/s11224-016-0816-8, https://link. springer.com/article/10.1007/s11224-016-0816-8

Watson, J. D. - Crick, F. H. C. (1953): Molecular Structure of Nucleic Acids: A Structure for Deoxyribose Nucleic Acid. Nature, April 25, 171, 737-738. DOI: 10.1038/171737a0, http://scarc. library.oregonstate.edu/coll/pauling/dna/papers/corr68.11-reprint-19530425.html 